\title{
Impacts of Organic Sources on the Ozone Depletion Events in Arctic Spring
}

\author{
Zhaohuan Liu and Le Cao*
}

Published: 15 July 2016

Key Laboratory for Aerosol-Cloud-Precipitation of China Meteorological Administration, Nanjing University of Information Science and Technology, Nanjing 210044, China

* Correspondence: le.cao@nuist.edu.cn

\begin{abstract}
Impacts of atmospheric halogens on the ozone depletion events (ODEs) in polar boundary layer have been under investigation since the discovery of negative correlation between atmospheric ozone and bromine. By simulating an ODE in a box model KINAL, this study focuses on the influence of natural organic sources on the ozone depletion. An estimation of bromine flux from Arctic plantation is given as $6.3 \times 10^{6}$ molec. $\mathrm{Br} /\left(\mathrm{cm}^{2} \cdot \mathrm{s}\right)$. Since there exists huge fluctuation in the flux, the bromine input is set to be adjustable, by which the impact of Arctic biological behavior on the tropospheric ozone can be predicted. Meanwhile, another nitrogen flux emitted from plants is also included in the model as the plants release considerable amount of nitrogen into the atmosphere, which alters the process of the ozone depletion. Different from the $\mathrm{Br}$ flux, the nitrogen flux implemented in the model remains relatively stable around $1 \times 10^{8}$ molec. $\mathrm{NO} /\left(\mathrm{cm}^{2} \cdot \mathrm{s}\right)$. The simulation results indicate that the type of the $\mathrm{Br}$ flux plays a relatively important role in the depletion of ozone. An average level of Br input may cause approximately a 1.0 day antedate to the ODE. In contrast to that, NO exerts minor impact on the ozone concentration, but an obvious force to the mixing ratio of $\mathrm{Br}$ species.
\end{abstract}

Keywords: ozone depletion; arctic; organic source; bromine flux

\section{Introduction}

In the boundary layer of polar regions, an ozone depletion event (ODE) is often observed in the early spring when sun rises [1]. During the observations in Barrow, Alaska [2], a sudden drop in ozone concentration is caught. In later observations, it is found that there exists a negative correlation between ozone and halogens, especially bromine in the boundary layer [3]. Similar tropospheric ODEs and the corresponding bromine accumulations have been confirmed by a series of observations in Arctic and Antarctic regions [4-10]. These observations also found sudden releases in halogens during Arctic ODEs, which are considered to be related to a catalytic cycle containing halogens, especially bromine whose ozone depleting effect is measured 45 times of chlorine [11]. The catalytic cycle mechanism can be described as a series of chemical reactions. With the reaction rates and the initial atmospheric composition given, the temporal evolution of any specific gaseous species can be obtained after a numerical analysis.

An ODE can be divided into three periods: the induction stage, the depletion stage and the end stage according to the temporal evolution of tracking gases [12]. In the induction stage, ozone is hardly consumed, with a depleting rate lower than $0.1 \mathrm{ppb} / \mathrm{h}$. During the induction stage, the major reactions taking place are the transformation of inert bromine to active gaseous $\mathrm{BrO}$ and $\mathrm{HOBr}$ at the saline surface. Physical structure of the ice/snow surface has a strong impact on the duration of the induction stage, as rough surface provides more space for halogen recycling heterogeneous reactions. In the 
The 1st International Electronic Conference on Atmospheric Sciences (ECAS 2016), 16-31 July 2016; Sciforum Electronic Conference Series, Vol. 1, 2016

second period named depletion stage, ozone is rapidly consumed at a rate higher than $0.1 \mathrm{ppb} / \mathrm{h}$. As the mixing ratio of $\mathrm{HOBr}$ increases during this period, a burst emission of brominated species from saline surface is observed, resulting in a rapid growth of bromine in the air. This abnormal burst of atmospheric bromine is the so-called "bromine explosion". When ozone concentration drops to $10 \%$ of its original value, it is considered that the depletion stage is over and the last period of the whole ozone depletion, the end stage, begins. During the end stage, as mixing ratio of HOBr reaches a peak, ozone continues to deplete to its minimum value, which is usually lower than $1 \mathrm{ppb}$. After that, $\mathrm{HOBr}$ is rapidly consumed while molecular $\mathrm{Br}$ becomes the major bromine species in the boundary layer. $\mathrm{Br}$ is later transformed into $\mathrm{HBr}$ by organic reactions.

Numerical models with different physical dimensions have been applied to investigate the ozone depleting and halogen recycling processes. 0-D models, or namely box models were first used in 1990s. In a box model research [13], the $\mathrm{Br}_{2}$ producing reaction:

$$
\mathrm{HOBr}(\mathrm{aq})+\mathrm{H}^{+}+\mathrm{Br}^{-} \longrightarrow \mathrm{Br}_{2}(\mathrm{aq})+\mathrm{H}_{2} \mathrm{O}
$$

is proposed. After switching off reaction (R1), model simulation shows that little ozone is consumed within 4 days, indicating that the aerosol phase production of $\mathrm{Br}_{2}$ is essential for ODEs. After that, modeling results of a steady-state model, BM, is compared to the observations [14,15], showing a significant impact of bromine chemistry on the mixing ratios of $\mathrm{RO}_{2}+\mathrm{HO}_{2}$ and $\mathrm{OH}$. Afterwards, a modified version of the photochemical box model MOCCA [16] adapted to polar conditions is developed, in order to investigate Arctic ODEs. Under this modified model MoccaIce [17], organic sources are initially prescribed. By analyzing the chemistry in Arctic ODEs by using MoccaIce, the rate of reactions between $\mathrm{Br}$ and $\mathrm{C}_{2} \mathrm{H}_{2}$ or $\mathrm{C}_{2} \mathrm{H}_{4}$ is found critical for the loss of bromide and the ozone budget in the troposphere. Role of iodine chemistry is also studied at the same time.

1-D models are first presented to inquire the relative importance of sea salt aerosols and fresh sea ice surface on the ozone destruction [18]. In 1-D models, mass transportation between vertical layers at different heights is considered. Source strengths of bromine and iodine required for sustaining the vertical structure of $\mathrm{BrO}$ and $\mathrm{IO}$ observed are invested by developing THAMO [19], which is a 1-D chemical transport model. In a comprehensive model study on ODEs, special attention is paid to the cloud microphysics by using a 1-D Lagrangian-mode boundary layer model MISTRA [20]. After modification, MISTRA was applied on the investigation of frost-flower derived aerosols, open leads and re-release processes on the snowpack during ODEs [21]. It is found that the recycling process on snow is the most important process for the existence of high-level bromine in the polar boundary layer. By coupling a snow module to MISTRA, a new model named MISTRA-SNOW is developed [22]. Studies on the basis of MISTRA-SNOW identified the role of in-snow photochemistry, indicating that the snowpack is able to provide adequate reactive bromine to sustain the $\mathrm{BrO}$ level observed [23]. In order to address the influence of reactive bromine released by the snowpack on the ozone loss in the polar boundary layer, a 1-D physicochemical model PHANTAS is developed, in which $\mathrm{HOBr}$ molecules are assumed vertically transported through the boundary layer and the snowpack. It is found that in the top layers and deeper layers of the snowpack, bromine release is driven by different mechanisms [24].

3-D model studies of the tropospheric ODEs in polar regions started from a regional chemistry transport model RCTM [25]. The correlation coefficient between observed and model-predicted ozone temporal variations at different sites are found above 0.5 . By adding a detailed bromine chemistry scheme to a global 3-D tropospheric model considering both local chemistry and long-range air transportation, $\mathrm{p}$-TOMCAT, lifetime and vertical profile of $\mathrm{BrO}$ are investigated [26]. Comparison with observations has proved its capability to simulate the high bromine level during the bromine explosion events. A global 3-D chemistry and transportation model GEM-AQ/Arctic is applied to investigate the spatial structure and time series of ozone and $\mathrm{BrO}$ in the Arctic boundary layer in spring [27]. Highly salt concentrated aerosols derived from the frost flowers assumed as the only halogen source 
The 1st International Electronic Conference on Atmospheric Sciences (ECAS 2016), 16-31 July 2016; Sciforum Electronic Conference Series, Vol. 1, 2016

in the troposphere, the air chemistry, the air temperature, atmospheric circulation and long-range transportation of pollutants are found to make great contribution to the polar ODEs in spring.

In the model studies mentioned above, the fact has been revealed that a comparatively low amount of bromine may lead to a significant enhancement to ozone depletion. Thus, any possible source of bromine should be concerned. Studies have shown that snow/ice surface emission is one of the major bromine sources, and some other inorganic sources have also been found. Snowpack with accumulated sea-salt particles is possibly the primary source of bromine in Arctic, which provides adequate bromine and surface area for the heterogeneous halogen recycling [28]. Existence of frost flowers is suggested to propose the formation of $\mathrm{CaCO}_{3}$-lack particle in the air, leading to the acidification of $\mathrm{SO}_{2}$ and $\mathrm{NO}_{2}$, which may accelerate the acid-catalyzed bromine explosion process [29]. Blowing snow is estimated to contribute $8 \%$ of the ozone loss in the polar spring [30]. However, the knowledge about organic halogen sources, which consist of natural and artificial releases of halogens, is still lacking. Respiration and degradation of plants, excrement of polar animals make up most proportion of the natural source, while artificial source mainly consists of biomass burning, shipping traffic and bromine-containing petrochemical organic products transportation. By adding halogen releases from some of these sources into a numerical model under study, impact of organic sources can be identified by comparing the results before and after the implementation of the specific sources.

Among the few Arctic plantations, macro-algae and moss are the most widespread species. Bromine produced by macro-algae is mainly concentrated in the form of $\mathrm{CHBr}_{3}$, while a relatively small amount of $\mathrm{CH}_{2} \mathrm{Br}_{2}$ also exists.

Due to the weak human activity inside the Arctic Circle, release from artificial sources is mainly considered as long-range transportation, which cannot be included in a 0-D model.

The main objectives of this research are listed below:

1. Analyze an ozone depletion numerically, estimate the input of different organic sources, and discuss the impact of specific organic sources on the ODE by adding them into a box model.

2. By adjusting flux input from different potential sources, predict the impact on the tropospheric ozone from biosphere behavior.

3. After advancing the box model with extra species and reactions, study the role of organic sources in releasing NOx species to enhance ODEs.

\section{Model Description}

The catalytic cycle considered in the model consists of a homogeneous reaction system which can be described as a differential equation:

$$
\frac{d \mathbf{c}}{d t}=f(\mathbf{c}, \mathbf{k})+\mathbf{F}
$$

where $\mathbf{c}$ stands for the species concentration vector, $\mathbf{k}$ denotes the reaction rate vector, and $\mathbf{F}$ represents the flux vector from the surface. Equation (1) is solved by using the box model KINAL [31], which is a FORTRAN program developed to solve the differential equation with a fourth-order semi-implicit Runge-Kutta method. The gaseous species and reactions included in KINAL can be found in [12], together with the reaction rates under $p=1 \mathrm{~atm}$. With a given initial condition $\left.c\right|_{t=0}=c_{0}$, known reantion rate vector $\mathbf{k}$ and flux data $\mathbf{F}$, the species concentration at any time can be solved by KINAL.

\subsection{Inorganic Sources}

As the horizontal transportation is not considered in the present box model, it is assumed that emission from ice/snow surface and aerosol surface are the only inorganic halogen sources, the dominate bromine-releasing reactions are the heterogeneous reactions:

$$
\mathrm{HOBr}+\mathrm{HBr} \stackrel{\text { aerosols }}{\longrightarrow} \mathrm{Br}_{2}+\mathrm{H}_{2} \mathrm{O}
$$


The 1st International Electronic Conference on Atmospheric Sciences (ECAS 2016), 16-31 July 2016; Sciforum Electronic Conference Series, Vol. 1, 2016

$$
\mathrm{HOBr}+\mathrm{H}^{+}+\mathrm{Br}^{-} \stackrel{\text { ice/snow }}{\longrightarrow} \mathrm{Br}_{2}+\mathrm{H}_{2} \mathrm{O}
$$

$\mathrm{The} \mathrm{Br}_{2}$ production rate of (R2) is given as below.

$$
\begin{gathered}
\frac{d}{d t}\left[\mathrm{Br}_{2}\right]=-\frac{d}{d t}[\mathrm{HOBr}]=k_{\mathrm{R} 2}[\mathrm{HOBr}] \\
k_{\mathrm{R} 2}=\left(\frac{a}{D_{\mathrm{g}}}+\frac{4}{v_{\text {therm }} \gamma}\right)^{-1} \alpha_{\mathrm{eff}}
\end{gathered}
$$

$a / D_{\mathrm{g}}$ represents the molecular diffusion limit, where $a$ is the aerosol radius and $D_{g}$ is the molecular diffusivity in the gas phase. $\gamma$ is the uptake coefficient of $\mathrm{HOBr}$ on sea salt aerosols. Mean molecular speed $v_{\text {therm }}$ is defined as $\sqrt{\frac{8 \mathrm{RT}}{\pi M_{\mathrm{HOBr}}}}$, where $M_{\mathrm{HOBr}}$ is the molar mass of $\mathrm{HOBr}$. $\mathrm{R}$ is the universal gas constant, and $T$ is the absolute temperature. The surface-volume coefficient $\alpha_{\text {eff }}$ is the ratio of total aerosol surface $A_{\text {aerosol }}$ and the total volume $V$ :

$$
\alpha_{\text {eff }}=\frac{A_{\text {aerosol }}}{V}
$$

It is assumed that $a=0.45 \mu \mathrm{m}, D_{\mathrm{g}}=0.2 \mathrm{~cm}^{2} \cdot \mathrm{s}^{-1}$ in the present research; For gaseous $\mathrm{HOBr}$ at mixing ratio of $10 \mathrm{ppt}, \gamma=0.12$; Given that aerosol particles are uniformly distriuted, calculation provides a typical $\alpha_{\text {eff }}$ value of $10^{-5} \mathrm{~cm}^{-1}$. Thus, the reaction rate of (R2) is estimated as $k_{\mathrm{R} 2}=6.14 \times 10^{-4} \mathrm{~s}^{-1}$ for 10 ppt of $\mathrm{HOBr}$.

Likely, for (R3) occurring at ice/snow surfaces,

$$
k_{\mathrm{R} 3}[\mathrm{HOBr}]=-\frac{d}{d t}[\mathrm{HOBr}]=k_{\mathrm{d}}[\mathrm{HOBr}]
$$

The deposition rate constant $k_{\mathrm{d}}$ is defined as:

$$
k_{\mathrm{d}}=\frac{v_{\mathrm{d}}}{L_{\mathrm{mix}}} \beta
$$

where $v_{\mathrm{d}}$ is the deposition velocity at ice/snow surfaces, and $L_{\text {mix }}$ is the typical height of a stable mixing layer, while $\beta$ is the reactive surface ratio coefficient, defined as the ratio of reactive surface area and the flat surface area.

A typical polar mixing layer height is believed to reside in a range from near zero to over $1000 \mathrm{~m}$ [32]. Following former researches [12,33], $L_{\text {mix }}$ is assumed as $200 \mathrm{~m}$, where $\nu_{\mathrm{d}}$ estimated as $0.605 \mathrm{~cm} \cdot \mathrm{s}^{-1} . \beta$ is determined by the physical structure of the surface, varying from 1 to $10^{3}$. In the present research, $\beta$ is set as 1 .

\subsection{Organic Sources}

Halogens from organic sources are then added into KINAL as follows.

\subsubsection{Macro-Algaes}

Macro-algal bromine exists mainly in the form of bromine-substituted methanes $\left(\mathrm{CHBr}_{3}, \mathrm{CH}_{2} \mathrm{Br}_{2}\right.$, $\mathrm{CH}_{3} \mathrm{Br}$ ). Macro-algaes produce around 70\% of the world's bromoform [34]. Production rate of $\mathrm{CHBr}_{3}$, $\mathrm{CH}_{2} \mathrm{Br}_{2}$ and $\mathrm{CH}_{3} \mathrm{Br}$ are estimated $1.7 \times 10^{2}, 2.8$ and $0.1 \mathrm{Gg} / \mathrm{yr}$ respectively at global scale, which is equivalent to $1 \times 10^{9} \mathrm{~mol} \mathrm{Br} / \mathrm{yr}$ [35], or $5.3 \times 10^{6} \mathrm{molec} . \mathrm{Br} /\left(\mathrm{cm}^{2} \cdot \mathrm{s}\right)$ after spatial average. 
The 1st International Electronic Conference on Atmospheric Sciences (ECAS 2016), 16-31 July 2016; Sciforum Electronic Conference Series, Vol. 1, 2016

Laboratory researches suggest that the emission rate of macro-algae ranges around 124-5434 ng $\mathrm{CHBr}_{3} /(\mathrm{g}$ dry weight.h), and emission rate in darkness is about half of that in the light [36]. Peak density of macro-algal biomass in Arctic is observed in mid-May, ranging within 400-600 $\mathrm{g} \mathrm{dwt} / \mathrm{m}^{2}$ [36]. Growth rate of the biomass is measured to range from 10 to $30 \mathrm{~g} \mathrm{dwt} /\left(\mathrm{m}^{2} \cdot \mathrm{d}\right)$, limited by the light condition. For an ODE taking place in early spring, the biomass density of macro-algaes can be assumed around $300 \mathrm{~g} \mathrm{dwt} / \mathrm{m}^{2}$. Thus, the overall estimation of macro-algal bromine production rate can be given as $3 \times 10^{8}-1 \times 10^{10}$ molec. $\mathrm{Br} /\left(\mathrm{cm}^{2} \cdot \mathrm{s}\right)$.

The bromine-substituted methane species take part in the reaction mechanism through reactions (R4) and (R5) as follows [34].

$$
\begin{aligned}
& \mathrm{CHBr}_{3}+\mathrm{H}_{2} \mathrm{O} \longrightarrow \mathrm{CH}_{2} \mathrm{Br}_{2}+\mathrm{HOBr} \\
& \mathrm{Br}_{2}+\mathrm{H}_{2} \mathrm{O} \longleftrightarrow \mathrm{HOBr}+\mathrm{H}^{+}+\mathrm{Br}^{-}
\end{aligned}
$$

The bromine hydrolysis reaction (R5) is promoted to produce HOBr under the alkalescent seawater condition [37]. Although bromine-substituted methane is not contained in the recent KINAL model, the ozone depleting effect can be considered in the form of $\mathrm{HOBr}$ release. Most of the released $\mathrm{HOBr}$ is consumed by reactions with dissolved organic matter (DOM). Taking the assumption that $99 \%$ of $\mathrm{HOBr}$ react with DOM [38], the remaining $1 \%$ can cause an area-normalized emission of $0.07-3.2 \mathrm{nmol} /\left(\mathrm{m}^{2} \cdot \mathrm{h}\right)$, or $1.2 \times 10^{5}-5.4 \times 10^{6}$ molec. $/\left(\mathrm{cm}^{2} \cdot \mathrm{s}\right)$, which matches the global estimation well.

However, other researches indicate that the primary $\mathrm{Br}$ emission is $\mathrm{Br}_{2}$ and $\mathrm{BrCl}$ release, which account for more than $40 \%$ of the total bromine emission [38]. According to reaction (R5), taking the $\mathrm{HOBr}$ source assumption, the simulation of ozone depletion should be more rapid than the reality, for unit amount of $\mathrm{HOBr}$ causes double amount of reactive bromine in the air.

Since there is no precise evaluation about $\mathrm{Br}$ releases, different proportions of plant-releasing $\mathrm{HOBr}$ and $\mathrm{Br}_{2}$ are examined, while the $\mathrm{BrCl}$ emission is ignored.

\subsubsection{Moss and Other Polar Plants}

On the tundra at lower latitudes in the Arctic region, there is a larger variety of vegetation. Aboveground live biomass provided by 6 individual functional types (mosses, lichens, forbs, sedges, deciduous shrubs and evergreen shrubs) are generated according to field data [39]. The spatial mean value of the total biomass field is estimated $694 \mathrm{~g} / \mathrm{m}^{2}$. Halogens released from shrubs does not play an important role in the ODE for its low producing rate [40]. Mosses and lichens are the major bromine-releasing plant types, whose biomass density remains stable under global warming [41]. Spatial averaged live biomass of mosses and lichens are estimated 300 and $50 \mathrm{~g} \mathrm{dwt} / \mathrm{m}^{2}$ respectively. Assuming that mosses and lichens have equivalent capability of releasing bromine as macro-algae species, the flux from tundra landscape can be set as $6.18 \times 10^{6} \mathrm{molec} . /\left(\mathrm{cm}^{2} \cdot \mathrm{s}\right)$.

Considering the polar area is a $2.1 \times 10^{7} \mathrm{~km}^{2}$ spherical crown within the Arctic Circle, $60 \%$ of which covered by ocean, while $5.05 \times 10^{6} \mathrm{~km}^{2}$ of the land part can be referred to as vegetated [42]. After all, bromine from the plant source can be estimated as approximately $6.3 \times 10^{6} \mathrm{molec} . \mathrm{Br} /\left(\mathrm{cm}^{2} \cdot \mathrm{s}\right)$ by spatial mean.

The initial mixing ratios of different gaseous species are listed in Table 1; Emission fluxes from inorganic ice/snow surface source and organic sources are listed in Table 2. Species not listed in Table 1 have a mixing ratio of 0 . 
The 1st International Electronic Conference on Atmospheric Sciences (ECAS 2016), 16-31 July 2016; Sciforum Electronic Conference Series, Vol. 1, 2016

Table 1. Initial mixing ratio of trace gaseous species in the polar boundary layer [12].

\begin{tabular}{cc}
\hline Species & Mixing Ratio \\
\hline $\mathrm{O}_{3}$ & $40 \mathrm{ppb}$ \\
$\mathrm{Br}_{2}$ & $0.3 \mathrm{ppt}$ \\
$\mathrm{HBr}$ & $0.01 \mathrm{ppt}$ \\
$\mathrm{CH}_{4}$ & $1.9 \mathrm{ppm}$ \\
$\mathrm{CO}_{2}$ & $371 \mathrm{ppm}$ \\
$\mathrm{CO}$ & $132 \mathrm{ppb}$ \\
$\mathrm{HCHO}$ & $100 \mathrm{ppt}$ \\
$\mathrm{CH}_{3} \mathrm{CHO}$ & $100 \mathrm{ppt}$ \\
$\mathrm{C}_{2} \mathrm{H}_{6}$ & $2.5 \mathrm{ppb}$ \\
$\mathrm{C}_{2} \mathrm{H}_{4}$ & $100 \mathrm{ppt}$ \\
$\mathrm{C}_{2} \mathrm{H}_{2}$ & $600 \mathrm{ppt}$ \\
$\mathrm{C}_{3} \mathrm{H}_{8}$ & $1.2 \mathrm{ppb}$ \\
$\mathrm{H}_{2} \mathrm{O}$ & $800 \mathrm{ppm}$ \\
\hline
\end{tabular}

Table 2. Flux rates from different sources.

\begin{tabular}{ccc}
\hline \multirow{2}{*}{ Species } & \multicolumn{2}{c}{ Flux Rates [molec./(cm $\left.\left.{ }^{2} \cdot \mathbf{s}\right)\right]$} \\
\cline { 2 - 3 } & Inorganic Sources [12] & Natural Organic Sources \\
\hline $\mathrm{H}_{2} \mathrm{O}_{2}$ & $1.0 \times 10^{8}$ & \\
$\mathrm{HCHO}$ & $6.0 \times 10^{7}$ & \\
$\mathrm{HOBr}$ and $\mathrm{Br}_{2}$ & & $6.3 \times 10^{6}$ molecules of $\mathrm{Br}$ (average) \\
\hline
\end{tabular}

\subsection{Model Implementation-Adding Nitrogen}

Plants are the major organic bromine source, while their capability of emitting nitrogen-related species is also notable. KINAL is improved by adding nitrogen species and relating reactions into it, in order to get better simulating results. The major nitrogen species emitted by plants are $\mathrm{NO}$ and $\mathrm{N}_{2} \mathrm{O}$, among which $\mathrm{N}_{2} \mathrm{O}$ does not participate in the ozone depleting cycle.

NO emission from macro-algae reaches a steady rate of $0.5-1 \mathrm{nmol} /(\mathrm{mg}$ chlorophyll.h) after illumination [43]. Observations of chlorophyll density varies around $6-18 \mathrm{mg} / \mathrm{m}^{2}$ [44]. Thus, NO emission from macro-algaes ranges within $5 \times 10^{7}-3 \times 10^{8} \mathrm{molec} . /\left(\mathrm{cm}^{2} \cdot \mathrm{s}\right)$. For rough estimation, an emission of $1 \times 10^{8} \mathrm{molec} . /\left(\mathrm{cm}^{2} \cdot \mathrm{s}\right)$ is assumed. The initial mixing ratio and flux rates of nitrogen species are listed in Table 3.

Table 3. Initial mixing ratios and flux rates of nitrogen species added into KINAL.

\begin{tabular}{cccc}
\hline \multirow{2}{*}{ Species } & \multirow{2}{*}{ Initial Mixing Ratio [12] } & \multicolumn{2}{c}{ Flux Rates [molec./(cm $\left.\left.{ }^{2} \cdot \mathbf{s}\right)\right]$} \\
\cline { 3 - 4 } & & Inorganic Sources [12] & Organic Sources \\
\hline $\mathrm{NO}$ & $5 \mathrm{ppt}$ & $1.6 \times 10^{7}$ & $1 \times 10^{8}$ \\
$\mathrm{NO}_{2}$ & $10 \mathrm{ppt}$ & $1.6 \times 10^{7}$ & \\
$\mathrm{HONO}$ & 0 & $1.6 \times 10^{7}$ & \\
\hline
\end{tabular}

\section{Results and Discussion}

\subsection{Bromine Model}

Simulation results of adding organic bromine sources are shown in Figure 1. In the first few days of the induction stage, the major change in bromine species is the growth of $\mathrm{HOBr}$ and $\mathrm{BrO}$. With the increase in $\mathrm{HOBr}$, large amount of inert bromine in the ice/snow surface is emitted through heterogeneous reactions, which causes a rapid increase in the total atmospheric bromine. After the induction stage, drop in ozone concentration results in a decline in the oxidability of atmosphere, and 
The 1st International Electronic Conference on Atmospheric Sciences (ECAS 2016), 16-31 July 2016; Sciforum Electronic Conference Series, Vol. 1, 2016

the reducing gases such as $\mathrm{HBr}$ and $\mathrm{Br}$ start to grow vigorously. At the end of the depletion stage, $\mathrm{BrO}$ and $\mathrm{HOBr}$ reach their peak values of about 60 and 90 ppt, and then quickly deplete. Meanwhile, $\mathrm{Br}$ becomes the major atmospheric bromine, reaching a peak of more than $150 \mathrm{ppt}$. In the end stage, $\mathrm{Br}$ is consumed by aldehydes in the troposphere [12], leaving high concentration of $\mathrm{HBr}$ in the air.

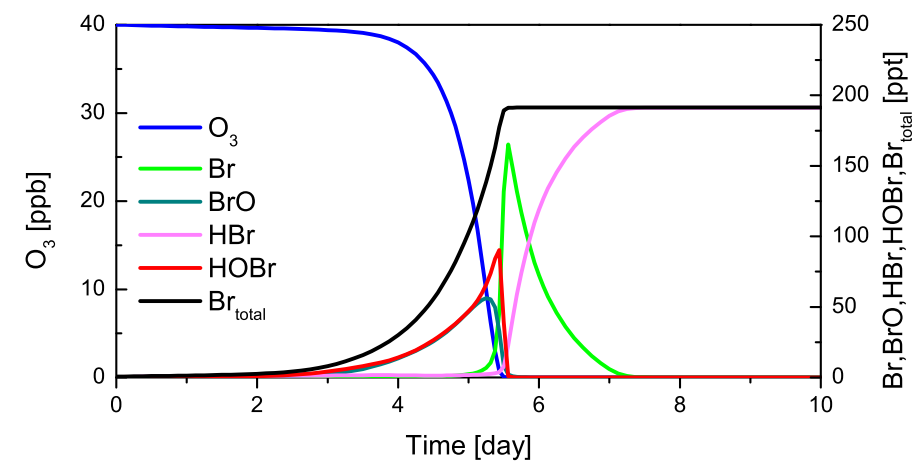

(a)

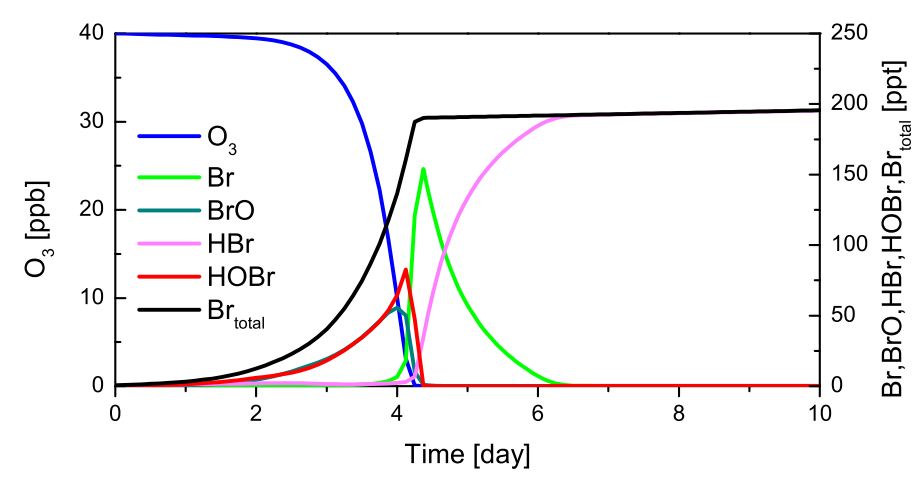

(b)

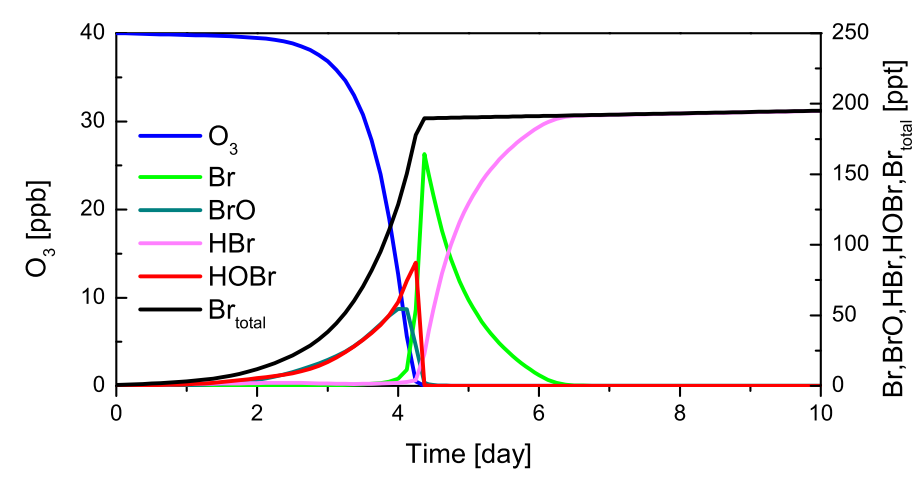

(c)

Figure 1. Simulated temporal evolution of bromine species and ozone when there exists: (a) only inorganic sources; (b) norganic and vegetal $\mathrm{HOBr}$ source; (c) inorganic and vegetal $\mathrm{Br}_{2}$ source.

Existence of direct bromine input causes significant impact on the ozone depletion, as shown in Figure $1 \mathrm{~b}$,c. After adding organic sources, ozone depletion is greatly fastened, while peaks of $\mathrm{HOBr}, \mathrm{Br}$ and $\mathrm{BrO}$ are also antedated. However, time for these bromine-related gases to completely disappear in the boundary layer from their peaks is not reduced. Period from $\mathrm{Br}$ peak to $\mathrm{Br}$ depletion remains about 2.0 days. As shown in Table 4, for an average level of either $\mathrm{HOBr}$ and $\mathrm{Br}_{2}$ source input, the induction stage is reduced for more than 1 day, while duration of the depletion stage lasts for around 1.0 day, not obviously influenced. Type of the source input does not show much importance. Figure 2 
The 1st International Electronic Conference on Atmospheric Sciences (ECAS 2016), 16-31 July 2016; Sciforum Electronic Conference Series, Vol. 1, 2016

shows the difference caused by source type. When $\mathrm{Br}_{2}$ makes up $90 \%$ of the total bromine emission (the highest $\mathrm{Br}_{2}$ ratio reported), simulation shows no obvious difference against the situation when $\mathrm{Br}_{2}$ accounts for $40 \%$ of the totality.

Table 4. Peak time and values of gaseous species, and stage beginning time under average level of organic source input.

\begin{tabular}{ccccccccc}
\hline & \multicolumn{3}{c}{ Peak Time (day) } & \multicolumn{3}{c}{ Peak Value (ppt) } & \multirow{2}{*}{ Depletion Stage (day) } & \multirow{2}{*}{ End Stage (day) } \\
\cline { 2 - 6 } & $\mathbf{H O B r}$ & $\mathbf{B r}$ & $\mathbf{B r O}$ & $\mathbf{H O B r}$ & $\mathbf{B r}$ & $\mathbf{B r O}$ & & \\
\hline Inorganic Only & 5.4 & 5.6 & 5.3 & 90 & 165 & 55 & 4.4 & 5.4 \\
Vegetal [HOBr] & 4.1 & 4.4 & 4.0 & 83 & 154 & 56 & 3.2 & 4.1 \\
Vegetal [BR 2$]$ & 4.2 & 4.4 & 4.1 & 87 & 165 & 54 & 3.2 & 4.2 \\
\hline
\end{tabular}

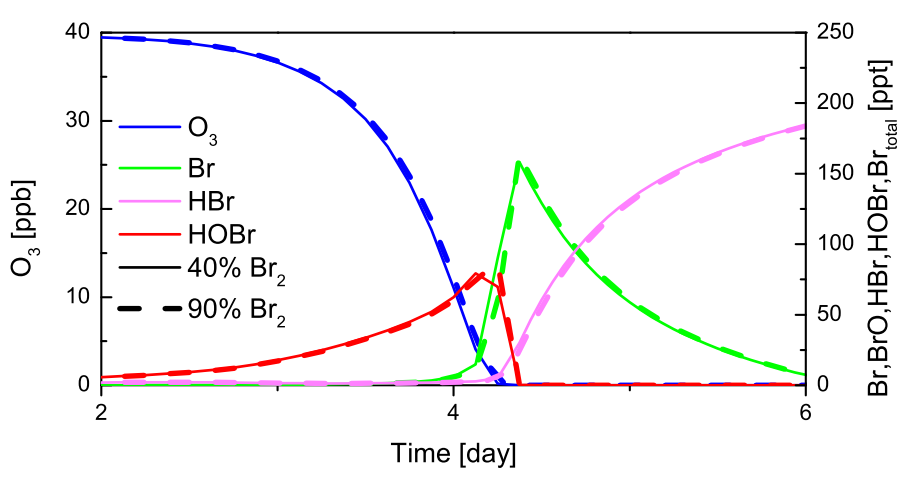

Figure 2. imulated temporal evolution of $\mathrm{O}_{3}, \mathrm{Br}, \mathrm{HBr}$ and $\mathrm{HOBr}$ with different ratio of $\mathrm{Br}_{2}$ input when there is an average input of bromine. Dash lines represent high $\mathrm{Br}_{2}$ ratio (90\%).

In KINAL, $\mathrm{HOBr}$ acts as a reactant in three reactions: $\mathrm{HOBr}+h v, \mathrm{HOBr}+\mathrm{HBr}$, and $\mathrm{HOBr}+\mathrm{H}^{+}+\mathrm{Br}^{-}$. The latter two reactions double the bromine input to the boundary layer. If they are the dominant reactions taking place in the induction stage, the $\mathrm{Br}_{2}$ proportion should have significant impact on the behavior of ozone. Because of the existence of:

$$
\mathrm{HOBr}+h v \longrightarrow \mathrm{OH}+\mathrm{Br}
$$

and its relatively high rate, most of directly released $\mathrm{HOBr}$ is consumed through photolysis process in the first few days of an ODE. After gaseous $\mathrm{HOBr}$ is accumulated after the induction stage, heterogeneous reactions $(\mathrm{HOBr}+\mathrm{HBr})$ and $\left(\mathrm{HOBr}+\mathrm{H}^{+}+\mathrm{Br}^{-}\right)$become the major sink of $\mathrm{HOBr}$.

Due to the weak impact of bromine source type on the whole event, assumption is taken in the present research that $60 \%$ of bromine released from plants is concentrated in $\mathrm{HOBr}$.

Since the natural source emission fluctuates greatly around the mean valus, an input adjustment is conducted in order to study ODEs under different levels of bromine release. As shown in Figure 3, the ozone depleting rate at the depletion stage remain around a fixed value under different source intensities. As source input increases, the induction stage is shortened, while duration of the depletion stage is not significantly influenced. However, the induction stage reduction is not limitless. For a higher source intensity, the shortening effect on the induction stage becomes slighter. 


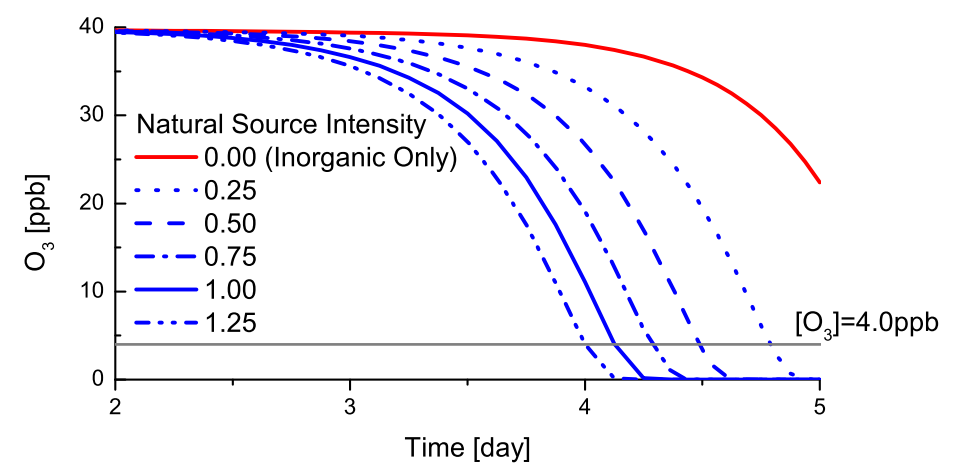

Figure 3. Simulated temporal evolution of $\mathrm{O}_{3}$ under different intensity of natural sources. Natural source intensity indicates the relative ratio of natural source emission and its mean value.

\subsection{Nitrogen Implementation}

After the addition of nitrogen $(\mathrm{N})$, enhancing effect of organic source on the ozone depletion is confirmed, as shown in Figure 4. In the induction stage and the depletion stage, behavior of the trace gases are not significantly influenced by the nitrogen input. Large amount of NO input from organic sources causes a lesser enhancement to ozone depletion, which leads to a 0.2 day antedate to the induction stage. As shown in Table 5 , due to the 0.2 day speeding effect, the peaks listed are all put forward at the same extent.

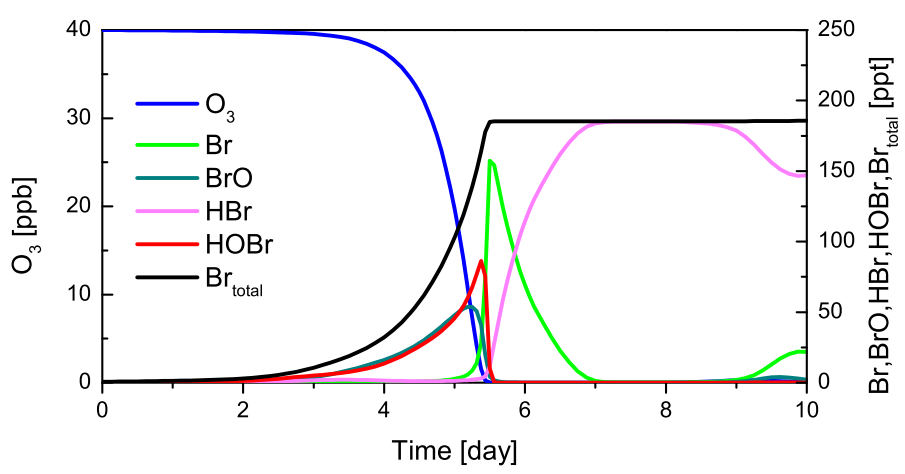

(a)

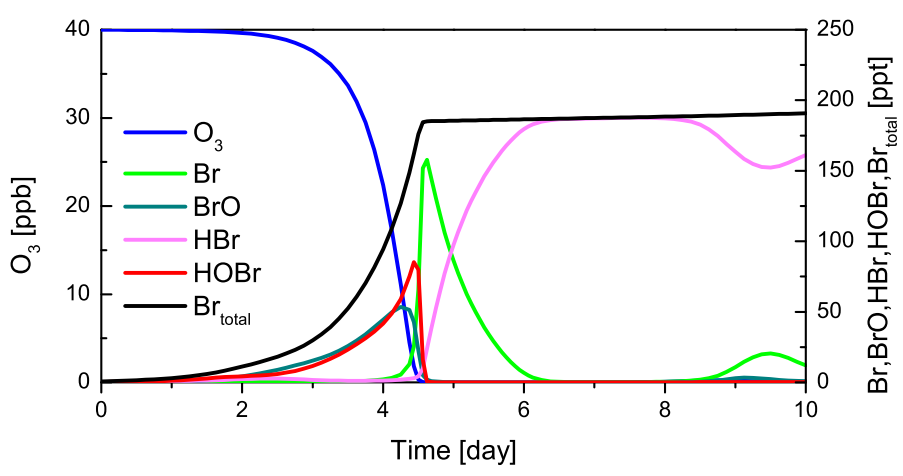

(b)

Figure 4. Cont. 
The 1st International Electronic Conference on Atmospheric Sciences (ECAS 2016), 16-31 July 2016; Sciforum Electronic Conference Series, Vol. 1, 2016

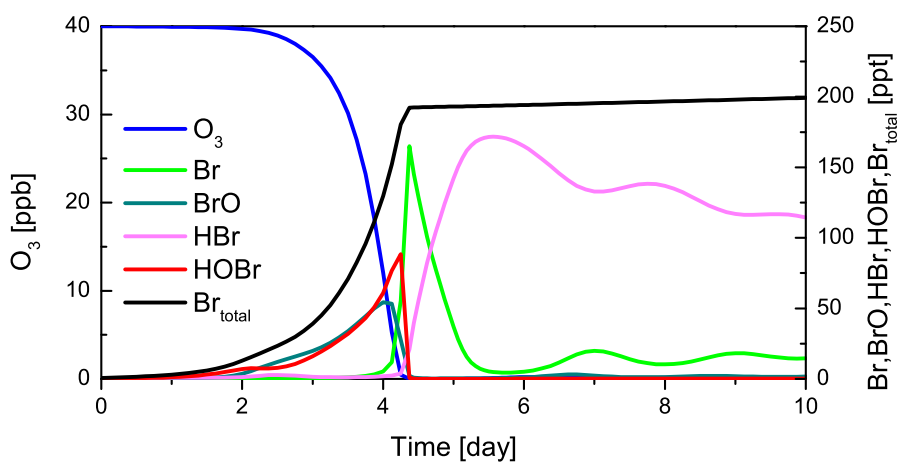

(c)

Figure 4. Simulate temporal evolution of bromine species and ozone when there exists: (a) inorganic sources only; (b) inorganic sources and organic bromine sources; (c) inorganic sources and complete organic source.

Table 5. Peak time and values of specific events under different organic source input, as the organic source consists of average level of $\mathrm{Br}$ and $\mathrm{N}$ input at the same time.

\begin{tabular}{lcccc}
\hline & & Br Peak & HOBr Peak & Br $_{\text {total }}$ Stability \\
\hline \multirow{2}{*}{ Time (day) } & Br Only & 4.6 & 4.4 & 4.6 \\
& Br and N & 4.4 & 4.2 & 4.4 \\
\hline \multirow{2}{*}{ Value (ppt) } & Br Only & 158 & 85 & 185 \\
& Br and N & 164 & 88 & 192 \\
\hline
\end{tabular}

As the model implementation consists of heterogeneous reactions:

$$
\begin{aligned}
& \mathrm{BrONO}_{2}+\mathrm{H}_{2} \mathrm{O} \stackrel{\text { aerosols }}{\longrightarrow} \mathrm{HOBr}+\mathrm{HNO}_{3} \\
& \mathrm{BrONO}_{2}+\mathrm{H}_{2} \mathrm{O} \stackrel{\text { ice/snow }}{\longrightarrow} \mathrm{HOBr}+\mathrm{HNO}_{3}
\end{aligned}
$$

Addition of nitrogen species provides extra approaches to release bromine from the inert phase, resulting in extra atmospheric bromine, which causes direct enhancement to the ODE. On the other hand, NO has great potential to form tropospheric ozone [45], which may decelerate the ozone depletion. In the present research, the total effects of organic NO emission makes the ODE slightly enhanced.

Simulation of N species are shown in Figure 5. PAN and HONO are the major nitrogen compounds in the boundary layer. PAN is the major nitrogen species after the induction stage, whose mixing ratio keeps increasing undil day 5.1. After that, PAN is slowly consumed, dropping from the 75 ppt peak.

Rather than ozone, the bromine vestige left in the boundary layer after the ODE is more influenced by the $\mathrm{N}$ input. According to Figure 4c, a declining trend is expected in $\mathrm{HBr}$. At the end of simulation, mixing ratio of $\mathrm{HBr}$ drops to approximately $120 \mathrm{ppt}$. On the contrary, former-depleted $\mathrm{Br}$ is accumulated again, fluctuating around $15 \mathrm{ppt}$.

Temporal evolution of bromine species in the ODE is shown in Figure 6. Mixing ratio of $\mathrm{BrNO}_{2}$ keeps increasing after day 4, reaching $70 \mathrm{ppt}$ at the end of simulation. Forming rate of $\mathrm{BrNO}_{2}$ and consuming rate of $\mathrm{HBr}$ are roughly equivalent, indicating that transformation from $\mathrm{HBr}$ to $\mathrm{BrNO}_{2}$ is an important reaction taking place in the end stage.

As shown in Figure 7, form if gaseous species in the boundary layer differs significantly as NO input from organic sources changes. Increase in $\mathrm{NO}$ source intensity enhances the transformation from $\mathrm{HBr}$ to $\mathrm{BrNO}_{2}$. When there is a NO input of $1.5 \times 10^{8}$ molec. $/\left(\mathrm{cm}^{2} \cdot \mathrm{s}\right)$, which can be easily obtained with warm weather and temperature condition, $\mathrm{BrNO}_{2}$ takes almost equal proportion in the total 
The 1st International Electronic Conference on Atmospheric Sciences (ECAS 2016), 16-31 July 2016; Sciforum Electronic Conference Series, Vol. 1, 2016

bromine as $\mathrm{HBr}$. It can be predicted that $\mathrm{BrNO}_{2}$ should become the major atmospheric bromine species after the ODE for a higher NO source intensity caused by climate change or ocean eutrophication.

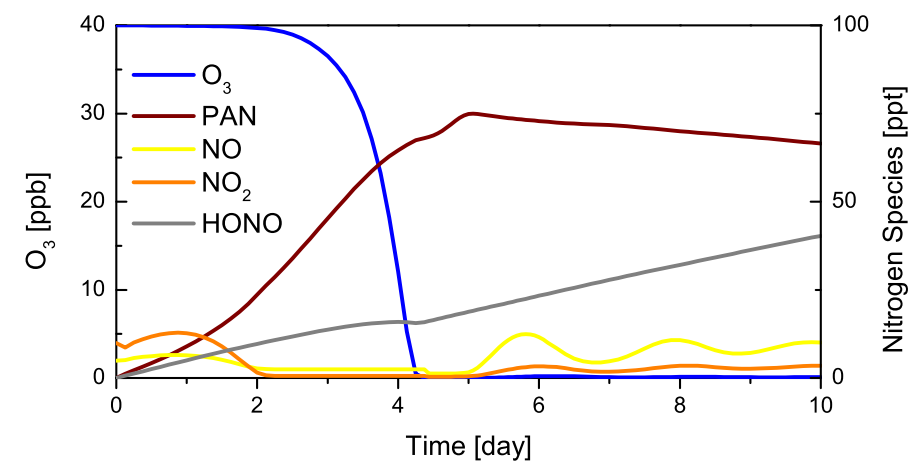

Figure 5. Simulated temporal evolution of major atmospheric nitrogen species during the ODE under average $\mathrm{Br}$ and $\mathrm{N}$ input of organic sources. PAN stands for peroxyacetyl nitrate $\left(\mathrm{CH}_{3} \mathrm{CO}_{3} \mathrm{NO}_{2}\right)$.

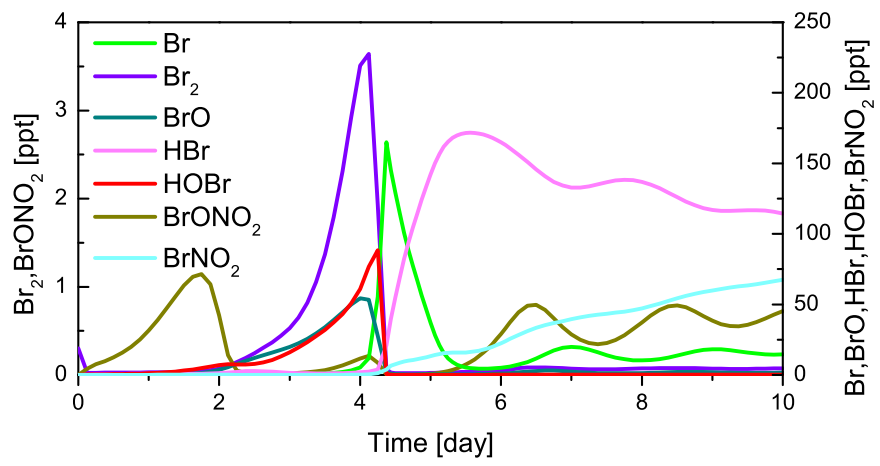

Figure 6. Simulated temporal evolution of bromine species under inorganic and organic sources after adding $\mathrm{N}$ to the model.

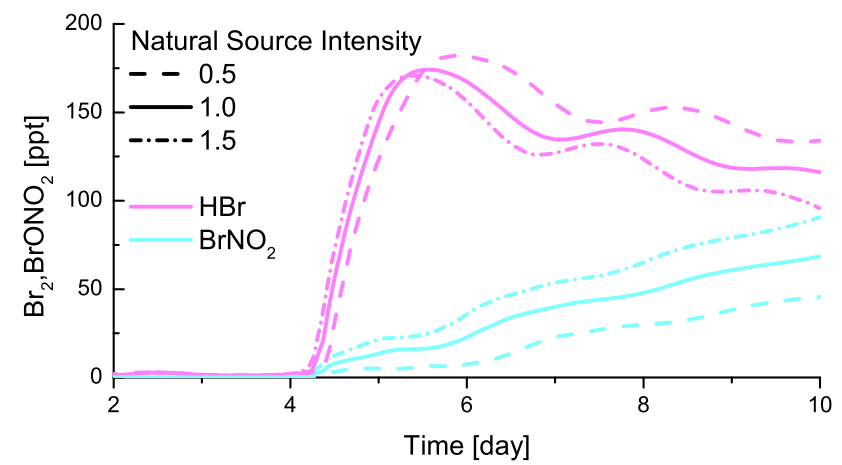

Figure 7. Simulated temporal evolution of $\mathrm{HBr}$ and $\mathrm{BrNO}_{2}$ under different $\mathrm{NO}$ natural source intensity. Natural source intensity indicates the relative ratio of natural source emission and its mean value.

\section{Conclusions}

Existence of the organic source addresses significant impact on Arctic ODEs. The major input of the local organic source is flux from plants, while other inputs are not considered in the present model. Flux from plants mainly consists of emission from macro-algaes, tundra-based mosses and lichens, while minor contribution is made by grasses and shrubs. In the present research, fluxes from organic 
The 1st International Electronic Conference on Atmospheric Sciences (ECAS 2016), 16-31 July 2016; Sciforum Electronic Conference Series, Vol. 1, 2016

sources are divided into two parts: the bromine input and the nitrogen input. The bromine input is considered to be originated from bromine-substituted methane. The organic bromine input applied to the recent model is assumed to be a mixing emission of $\mathrm{HOBr}$ and $\mathrm{Br}_{2}$, whose composition does not apply much influence on the ODE. Bromine input enhances the ODE by reactivating inert Br beneath the ice/snow surface, and provides initial $\mathrm{Br}$ for the catalytic reaction cycle to consume ozone. There is a positive correlation between the bromine input and the reducing effect on duration of the induction stage, while the depletion stage is not significantly affected. For an average level of bromine input, the induction stage lasts for 3.2 days, which is 1.2 days shorter than that under no organic source input.

The vast majority of the nitrogen input is NO emitted by various plants. NO input has an enhancement to the ODE, yet not as great as the bromine input. The induction stage is reduced for a negligible level of 0.2 days, mainly because of the bromine released by heterogeneous reactions. Changes in organic $\mathrm{N}$ input level leads to influence on the chemistry after the atmospheric $\mathrm{Br}$ stability. High organic $\mathrm{N}$ input causes transformation from $\mathrm{HBr}$ to $\mathrm{BrNO}_{2}$. When the $\mathrm{NO}$ flux reaches $1.5 \times 10^{8}$ molec. $/\left(\mathrm{cm}^{2} \cdot \mathrm{s}\right), \mathrm{BrNO}_{2}$ becomes major atmospheric bromine, replacing $\mathrm{HBr}$.

Acknowledgments: Thanks should be given to the financial supports from the National Natural Science Foundation of China (No. 41375044), the Natural Science Foundation of Jiangsu Province (No. 2015s042), the Double Innovation Talent Program (No. R2015SCB02), the Polar Strategic Foundation (No. 20150308) and the Startup Foundation for Introducing Talent of NUIST (No. 2014r066).

Author Contributions: Zhaohuan Liu made the estimation of fluxes from organic sources, and conducted most of the analyzing and writing job; Le Cao accomplished the work in building up the chemistry reaction mechanism, calculating the heterogeneous reaction rates, and specifying the inorganic sources.

Conflicts of Interest: The authors declare no conflict of interest.

\section{Abbreviations}

The following abbreviations are used in this manuscript:

$$
\begin{array}{ll}
\text { ODE } & \text { Ozone Depletion Event } \\
\text { PAN } & \text { Peroxyacetyl Nitrate } \\
\text { DOM } & \text { Dissolved Organic Matter }
\end{array}
$$

\section{References}

1. Solberg, S.; Schmidbauer, N.; Semb, A.; Stordal, F.; Øystein, H. Boundary-layer ozone depletion as seen in the Norwegian Arctic in spring. J. Atmos. Chem. 1996, 23, 301-332.

2. Oltmans, S.; Samuel, J. Surface ozone measurements in clean air. J. Geophys. Res. Oceans 1981, 86, 1174-1180.

3. Bottenheim, J.; Gallant, A.G.; Brice, K.A. Measurements of $\mathrm{NOy}$ species and $\mathrm{O}_{3}$ at $82^{\circ} \mathrm{N}$ latitude. Geophys. Res. Lett. 1986, 13, 113-116.

4. Frieß, U.; Hollwedel, J.; König-Langlo, G.; Wagner, T.; Platt, U. Dynamics and chemistry of tropospheric bromine explosion events in the Antarctic coastal region. J. Geophys. Res. Atmos. 2004, 109, 6305.

5. Wagner, T.; Ibrahim, O.; Sinreich, R.; Frieß, U.; Glasow, R.V. Enhanced tropospheric BrO over Antarctic sea ice in mid winter observed by MAX-DOAS on board the research vessel Polarstern. Atmos. Chem. Phys. 2007, 7, 3129-3142.

6. Helmig, D.; Oltmans, S.; Carlson, D.; Lamarque, J.F.; Jones, A.E. A review of surface ozone in the polar regions. Atmos. Environ. 2007, 41, 5138-5161.

7. Helmig, D.; Boylan, P.; Johnson, B.; Oltmans, S.; Fairall, C.; Staebler, R.; Weinheimer, A.; Orlando, J.; Knapp, D.J.; Montzka, D.D.; et al. Ozone dynamics and snow-atmosphere exchanges during ozone depletion events at Barrow, Alaska. J. Geophys. Res. Atmos. 2012, 117, 20303.

8. Jones, A.E.; Anderson, P.S.; Wolff, E.W.; Turner, J.; Rankin, A.M.; Colwell, S.R. A role for newly forming sea ice in springtime polar tropospheric ozone loss? Observational evidence from Halley station, Antarctica. J. Geophys. Res. Atmos. 2006, 111, 8306.

9. Jones, A.E.; Anderson, P.S.; Begoin, M.; Brough, N.; Hutterli, M.A.; Marshall, G.J.; Richter, A.; Roscoe, H.K.; Wolff, E.W. BrO, blizzards, and drivers of polar tropospheric ozone depletion events. Atmos. Chem. Phys. 2009, 9, 4639-4652. 
The 1st International Electronic Conference on Atmospheric Sciences (ECAS 2016), 16-31 July 2016;

Sciforum Electronic Conference Series, Vol. 1, 2016

10. Jones, A.E.; Anderson, P.S.; Wolff, E.W.; Roscoe, H.K.; Richter, A.; Brough, N.; Colwell, S.R. Vertical structure of Antarctic tropospheric ozone depletion events: Characteristics and broader implications. Atmos. Chem. Phys. 2010, 10, 7775-7794.

11. Daniel, J.S.; Solomon, S.; Portmann, R.W.; Garcia, R.R. Stratospheric ozone destruction: The importance of bromine relative to chlorine. J. Geophys. Res. Atmos. 1999, 104, 23871-23880.

12. Cao, L.; Sihler, H.; Platt, U.; Gutheil, E. Numerical analysis of the chemical kinetic mechanisms of ozone depletion and halogen release in the polar troposphere. Atmos. Chem. Phys. 2014, 14, 3771-3787.

13. Fan, S.M.; Jacob, D.J. Surface ozone depletion in Arctic spring sustained by bromine reactions on aerosols. Nature 1992, 359, 522-524.

14. Stutz, J.; Platt, U. Improving long-path differential optical absorption spectroscopy with a quartz-fiber mode mixer. Appl. Opt. 1997, 36, 1105-1115.

15. Tanner, D.J.; Jefferson, A.; Eisele, F.L. Selected ion chemical ionization mass spectrometric measurement of OH. J. Geophys. Res. Atmos. 1997, 102, 6415-6425.

16. Sander, R., Crutzen, P.J. Model study indicating halogen activation and ozone destruction in polluted air masses transported to the sea. J. Geophys. Res. Atmos. 1996, 101, 9121-9138.

17. Sander, R.; Vogt, R.; Harris, G.W.; Crutzen, P.J. Modelling the chemistry of ozone, halogen compounds, and hydrocarbons in the arctic troposphere during spring. Tellus Ser. B 1997, 49, 522-532.

18. Lehrer, E.; Hönninger, G.; Platt, U. A one dimensional model study of the mechanism of halogen liberation and vertical transport in the polar troposphere. Atmos. Chem. Phys. 2004, 4, 2427-2440.

19. Saiz-Lopez, A.; Plane, J.M.C.; Mahajan, A.S.; Anderson, P.S.; Bauguitte, S.J.-B.; Jones, A.E.; Roscoe, H.K.; Salmon, R.A.; Bloss, W.J.; Lee, J.D.; et al. On the vertical distribution of boundary layer halogens over coastal Antarctica: Implications for $\mathrm{O}_{3}, \mathrm{HO}_{x}, \mathrm{NO}_{x}$ and the $\mathrm{Hg}$ lifetime. Atmos. Chem. Phys. 2008, 8, 887-900.

20. Bott, A.; Trautmann, T.; Zdunkowski, W. A numerical model of the cloud-topped planetary boundary layer: Radiation, turbulence and spectral microphysics in marine stratus. Q. J. R. Meterolog. Soc. 1996, 122, 635-667.

21. Piot, M.; Glasow, R. The potential importance of frost flowers, recycling on snow, and open leads for ozone depletion events. Atmos. Chem. Phys. 2008, 8, 2437-2467.

22. Thomas, J.L.; Stutz, J.; Lefer, B.; Huey, L.G.; Toyota, K.; Dibb, J.E.; Glasow, R.V. Modeling chemistry in and above snow at Summit, Greenland-Part 1: Model description and results. Atmos. Chem. Phys. 2011, 11, 4899-4914.

23. Thomas, J L.; Dibb, J.E.; Huey, L.G.; Liao, J.; Tanner, D.; Lefer, B.; Glasow, R.V.; Stutz, J. Modeling chemistry in and above snow at Summit, Greenland-Part 2: Impact of snowpack chemistry on the oxidation capacity of the boundary layer. Atmos. Chem. Phys. 2012, 12, 6537-6554.

24. Foster, K.L; Plastridge, R.A.; Bottenheim, J.W.; Shepson, P.B.; Finlayson-Pitts, B.J.; Spicer, C.W. The role of Br 2 and $\mathrm{BrCl}$ in surface ozone destruction at polar sunrise. Science 2001, 291, 471-474.

25. Zeng, T.; Wang, Y.; Chance, K.; Browell, E.V.; Ridley, B.A.; Atlas, E.L. Widespread persistent near-surface ozone depletion at northern high latitudes in spring. Geophys. Res. Lett. 2003, 30, 2298.

26. Yang, X.; Cox, R.A.; Warwick, N.J.; Pyle, J.A.; Carver, G.D.; O'Connor, F.M.; Savage, N.H. Tropospheric bromine chemistry and its impacts on ozone: A model study. J. Geophys. Res. Atmos. 2005, 110, 23311.

27. Zhao, T.L.; Gong, S.L.; Bottenheim, J.W.; McConnell, J.C.; Sander, R.; Kaleschke, L.; Richter, A.; Kerkweg, A.; Toyota, K.; Barrie, L.A. A three-dimensional model study on the production of $\mathrm{BrO}$ and Arctic boundary layer ozone depletion. J. Geophys. Res. Atmos. 2008, 113, 24304.

28. Michalowski, B.A.; Francisco, J.S.; Li, S.M.; Barrie, L.A.; Bottenheim, J.W.; Shepson, P.B. A computer model study of multiphase chemistry in the Arctic boundary layer during polar sunrise. J. Geophys. Res. Atmos. 2000, 105, 15131-15145.

29. Sander, R.; Burrows, J.; Kaleschke, L. Carbonate precipitation in brine-a potential trigger for tropospheric ozone depletion events. Atmos. Chem. Phys. 2006, 6, 4653-4658.

30. Yang, X.; Pyle, J.A.; Cox, R.A.; Theys, N.; Van Roozendael, M. Snow-sourced bromine and its implications for polar tropospheric ozone. Atmos. Chem. Phys. 2010, 10, 7763-7773.

31. Turányi, T. KINAL-A program package for kinetic analysis of reaction mechanisms. Comput. Chem. 1990, 14, 253-254.

32. Stull Roland, B. An Introduction to Boundary Layer Meteorology; Springer Science \& Business Media, 2012; Volume 13. 
The 1st International Electronic Conference on Atmospheric Sciences (ECAS 2016), 16-31 July 2016;

Sciforum Electronic Conference Series, Vol. 1, 2016

33. Cao, L.; Platt, U.; Gutheil, E. Role of the boundary layer in the occurrence and termination of the tropospheric ozone depletion events in polar spring. Atmos. Environ. 2016, 132, 98-110.

34. Carpenter, L.J.; Liss, P.S. On temperate sources of bromoform and other reactive organic bromine gases. J. Geophys. Res. Atmos. 2000, 105, 20539-20547.

35. Manley, S.L.; Goodwin, K.; North, W.J. Laboratory production of bromoform, methylene bromide, and methyl iodide by macroalgae and distribution in nearshore southern California waters. Limnol. Oceanogr. 1992, 37, 1652-1650.

36. Cota, G.F.; Sturges, W.T. Biogenic bromine production in the Arctic. Mar. Chem. 1997, 56, 181-192.

37. Hill, V.L.; Manley, S.L. Release of reactive bromine and iodine from diatoms and its possible role in halogen transfer in polar and tropical oceans. Limnol. Oceanogr. 2009, 54, 812-822.

38. Thompson, C.R.; Shepson, P.B.; Liao, J.; Huey, L.G.; Cantrell, C.; Flocke, F.; Orlando, J. Bromine atom production and chain propagation during springtime Arctic ozone depletion events in Barrow, Alaska. Atmos. Chem. Phys. Discuss. 2016, 1-42, doi:10.5194/acp-2015-1039 .

39. Epstein, H.E.; Calef, M.P.; Walker, M.D.; Chapin, F.S., III; Starfield, A.M. Detecting changes in arctic tundra plant communities in response to warming over decadal time scales. Glob. Chang. Biol. 2004, 10, 1325-1334.

40. Nordmeyer, T.; Wang, W.; Ragains, M.L.; Finlayson-Pitt, B.; Spicer, C.W.; Plastridge, R.A. Unique products of the reaction of isoprene with atomic chlorine: Potential markers of chlorine atom chemistry. Geophys. Res. Lett. 1997, 24, 1615-1618.

41. Chapin, F.S., III; Shaver, G.R.; Giblin, A.E.; Nadelhoffer, K.J.; Laundre, J.A. Responses of arctic tundra to experimental and observed changes in climate. Ecology 1995, 76, 694-711.

42. Walker, D.A.; Raynolds, M.K.; Danils, F.J.A.; Einarsson, E.; Elvebakk, A.; Gould, W.A.; Katenin, A.E.; Kholod, S.S.; Markson, C.J.; Melnikov, E.S.; et al. The circumpolar Arctic vegetation map. J. Veg. Sci. 2005, 16, $267-282$.

43. Tischner, R.; Planchet, E.; Kaiser, W.M. Mitochondrial electron transport as a source for nitric oxide in the unicellular green alga Chlorella sorokiniana. FEBS Lett. 2004, 576, 151-155.

44. Cota, G.F.; Prinsenberg, S.J.; Bennett, E.B.; Loder, J.W.; Lewis, M.R.; Anning, J.L.; Watson, N.H.F.; Harris, L.R. Nutrient fluxes during extended blooms of Arctic ice algae. J. Geophys. Res. Oceans 1987, 92, 1951-1962.

45. Ryerson, T.B.; Trainer, M.; Angevine, W.M.; Brock, C.A.; Dissly, R.W.; Fehsenfeid, F.C.; Frost, G.J.; Goldan, P.D.; Holloway, J.S.; Hubler, G.; et al. Effect of petrochemical industrial emissions of reactive alkenes and NOx on tropospheric ozone formation in Houston, Texas. J. Geophys. Res. Atmos. 2003, 108, doi:10.1029/2002jd003070.

(C) 2016 by the authors; licensee MDPI, Basel, Switzerland. This article is an open access article distributed under the terms and conditions of the Creative Commons Attribution (CC-BY) license (http://creativecommons.org/licenses/by/4.0/). 